\title{
Pengaruh Penerapan Ongoing Assesment dalam Pembelajaran CTL Menggunakan Flip Chart
}

\author{
Della Dwi Andhini' ${ }^{1}$, Undang Rosidin ${ }^{1 *}$, Kartini Herlina ${ }^{1}$ \\ ${ }^{1}$ Program Studi Pendidikan Fisika, Fakultas Keguruan dan Ilmu Pendidikan, Universitas Lampung, Bandarlampung, Indonesia
}

DOI: $10.29303 /$ jppipa.v6i1.322

Sitasi: Andhini, D. D., Rosidin, U., Herlina, K. 2020. Pengaruh Penerapan Ongoing Assesment dalam Pembelajaran CTL Menggunakan Flip Chart. Jurnal Penelitian Pendidikan IPA (JPPIPA). 6 (1). pp. 75-80

\section{Article history}

Received: October $15^{\text {th }} 2019$

Revised: November $29^{\text {th }} 2019$

Accepted: December $23^{\text {th }} 2019$

*Corresponding Author: Undang Rosidin: Program Studi

Pendidikan Fisika, Fakultas

Keguruan dan Ilmu Pendidikan, universitas Lampung,

Bandarlampung, Indonesia;

Email: undangrosidin@gmail.com

\begin{abstract}
This study aims to determine the effect of ongoing assesment in collaborative teamwork learning using flip chart on students' collaborative abilities and cognitive skills. This research design used was one shot case design and one group pretest-posttest design. This study used one experiment class and students were given special treatment or teaching for some time. This treatment is the use of ongoing assessment in collaborative teamwork learning using flip chart on students'. The research data was taken from the value of observations and initial and final tests whose results were tested using the simple linear regression. Based on the results of the first hypothesis and the second hypothesis testing using simple linear regression with Asymp.Sig. (2-tailed) are both obtained 0,00 so $\mathrm{H}_{0}$ is rejected, which means the effect of ongoing assesment in collaborative teamwork learning using flip chart format influences the increase of collaborative abilities and cognitive skills. based on the value of the correlation coefficient $(r)$ in the simple linear regression test obtained 0.42 for the first hypothesis test which means, the effect of ongoing assessment incollaborative teamwork learning using flip charts has a good enough effect on collaborative abilities, which is equal to $42 \%$. Whereas in the second hypothesis test the correlation coefficient value $(r)$ obtained in a simple linear regression test obtained 0.90 , which means, the effect of ongoing assessment in collaborative teamwork learning using flip charts has a very good effect on cognitive skills, which is equal to $90 \%$.
\end{abstract}

Keywords: CTL (collaborative teamwork learning); Cognitive Skills; Flip Chart; Ongoing Assesment; Collaborative Abilities

Abstrak: Penelitian ini bertujuan untuk mengetahui pengaruh penerapan ongoing assesment dalam pembelajaran collaborative teamwork learning menggunakan flip chart terhadap kemampuan kolaboratif dan kemampuan kognitif siswa. Desain penelitian yang digunakan adalah One Shot Case Study dan One Group Pretest Posttest Design. Penelitian ini menggunakan satu kelas eksperimen dan siswa diberi perlakuan khusus atau pengajaran selama beberapa waktu. Perlakuan ini adalah penerapan ongoing assesment dalam pembelajaran collaborative teamwork learning menggunakan flip chart. Data penelitian diambil dari nilai observasi serta tes awal dan akhir yang hasilnya diuji menggunakan uji regresi linier sederhana. Berdasarkan hasil uji hipotesis pertama dan kedua menggunakan uji regresi linier sederhana dengan Asymp Sig. (2-tailed) masing-masing diperoleh sebesar 0,00 sehingga terdapat pengaruh penerapan ongoing assesment dalam pembelajaran collaborative teamwork learning menggunakan flip chart terhadap kemampuan kolaboratif dan kemampuan kognitif siswa. Ditinjau dari nilai koefisien korelasi $(r)$ pada uji regresi linier sederhana diperoleh 0,42 untuk uji hipotesis pertama yang artinya, penerapan ongoing assesment dalam pembelajaran collaborative teamwork learning menggunakan flip chart berpengaruh cukup baik terhadap kemampuan kolaboratif, yaitu sebesar $42 \%$. Sedangkan pada uji hipotesis kedua diperoleh nilai koefisien korelasi $(r)$ pada uji regresi linier sederhana diperoleh 0,90 yang artinya, penerapan ongoing assesment dalam pembelajaran collaborative teamwork learning menggunakan flip chart berpengaruh sangat baik terhadap 
kemampuan kognitif, yaitu sebesar $90 \%$.

Kata kunci: CTL (collaborative teamwork learning); Flip Chart; Kemampuan Kognitif Kemampuan Kolaboratif; Ongoing Assesment

\section{Pendahuluan}

Salah satu cara mewujudkan pembelajaran sesuai dalam Permendikbud No. 65 tahun 2013 adalah dengan menggunakan sistem penilaian yang sesuai yaitu penilai berkelanjutan (ongoing assesment). Selanjutnya, Permendikbud No. 65 tahun 2013 juga menjelaskan proses kegiatan penutup pada pembelajaran pendidik harus merefleksi untuk mengevaluasi seluruh aktivitas pembelajaran dan hasil yang diperoleh ditelaah untuk menemukan manfaatnya, lalu memberikan umpan balik terhadap proses dan hasil pembelajaran, serta melakukan tindak lanjut dalam bentuk tugas dan merencanakan pembelajaran berikutnya (Permendikbud, 2013). Penting sekali menerapkan ongoing assesment pada pembelajaran di sekolah sebagai bentuk penilaian otentik yang sudah seharusnya di terapkan secara baik.

Menurut Bishop (2010) pembelajaran abad 21 harus mengajarkan 4 kompetensi yaitu communication, collaboration, critical thinking, dan creativity. Beberapa kompetensi yang harus dimiliki oleh peserta didik yakni Collaboration skills dan Cognitiv abilities. Berdasarkan hasil observasi sebanyak $60 \%$ dari 10 responden pengajar pendidikan menengah yang ada di Lampung menyatakan telah menerapkan ongoing assesment pada pembelajaran. Namun, seperti di Sekolah Menengah Atas (SMA) 9 Bandar Lampung penerapan ongoing assesment di sekolah tersebut belum maksimal karena belum ada inventari penilaian indikator pencapaian, pengadaan jurnal kegiatan siswa, dan tes mingguan. Sama halnya di Sekolah Menengah Atas (SMA) Negeri 1 Natar, ongoing assesment yang diterapkanpun belum maksimal, belum ada kegiatan pengayaan rutin, belum ada penilaian setiap unit materi, dan belum ada kegiatan inventari penilaian indikator pencapaian. Sejumlah $60 \%$ pengajar menyatakan kemampuan kolaboratif peserta didik sudah baik dan $70 \%$ pengajar menyatakan kemampuan kognitif peserta didika sudah baik. Seperti di Sekolah Menengah Kejuruan (SMK) Negeri 1 Seputih Agung, kemampuan kolaboratif peserta didiknya sudah baik, namun belum sesuai dengan indikator kemampuan kolaboratif yang ada, guru hanya membiarkan peserta didik menjalankan proses pembelajaran sendiri seperti kerja kelompok atau berdiskusi dengan tidak menyertakan langkah-langkah pembelajaran yang jelas untuk mencapai indikator kemampuan kolaboratif. Sedangkan, untuk kemampuan kognitif disekolah tersebut menurut responden lebih buruk dari kemampuan kolaboratif yang dimiliki peserta didik di sekolah tersebut. Peserta didik di SMK tersebut lebih pandai melakukan praktik langsung dibandingkan dengan konsep fisika yang diajarkan di dalam kelas. Lain halnya di Sekolah Menengah Atas (SMA) Negeri 9 Bandar Lampung, kemampuan kognitif peserta didik lebih baik dibandingkan kemampuan kolaboratifnya. Menurut responden, peserta didik lebih aktif ketika belajar materi fisika di dalam kelas dibandingkan melaksanakan praktik langsung. Saat diskusi, peserta didik lebih bersikap acuh terhadap anggota kelompoknya. Sehingga, peserta didik yang berkemampuan kurang tetap pasif pada saat diskusi dan peserta didik yang berkemampuan baik makin aktif pada saat diskusi.

Penerapan ongoing assement dengan memberi feed back pada pembelajaran dapat meningkatkan hasil belajar fisika siswa Madrasah Aliyah Negeri (MAN) 1 Pringsewu Lampung (Rahmawati, et al). Penelitian lain menjelaskan terdapat pengaruh positif penerapan ongoing assesment teknik IF-AT terhadap hasil belajar siswa di Sekolah Menengah Atas (SMA) 1 Banyumas Pringsewu (Surahman, et al., 2013). Penelitian terkait penerapan ongoing assesment lainnya juga mengungkap bahwa penerapan ongoing assesment dapat meningkatkan hasil belajar siswa di Sekolah Menengah Atas (SMA) Negeri 1 Bukit Kemuning (Sari, et al., 2014). Berdasarkan beberapa hasil penelitian tersebut, ongoing assesment memang memiliki pengaruh positif dan dapat meningkatkan pengetahuan (kemampuan kognitif) terhadap sekolah yang terdiri dari siswa yang kurang aktif dan memiliki waktu pembelajaran yang kurang sehingga terkadang pemecahan masalah yang diberikan tidak diiringi dengan solusi dan langkah perbaikan. Ongoing assesment juga dapat mempengaruhi kemampuan kolaboratif siswa.

Berdasarkan permasalahan yang telah dipaparkan di atas maka adanya peningkatan kemampuan kolaboratif dan juga kemampuan kognitif siswa. Oleh karena itu, penelitian itu bertujuan untuk mendeskripsikan pengaruh penerapan ongoing assesment dalam pembelajaran collaborative teamwork 
learning menggunakan flip chart terhadap kemampuan kolaboratif dan kemampuan kognitif siswa.

\section{Metode}

Penelitian ini digolongkan dalam eksperimen semu atau quasi-experiment dengan one shot case study design dan one group preteset-posttest design. Penelitian ini menggunakan satu kelas sebagai sampel yang diambil menggunakan teknik cluster random sampling. Tahapan pembelajaran pada penelitian ini yaitu sesuai sintaks model pembelajaran collaborative teamwork learning, dan setiap pertemuannya diberlakukan tiga kali pengamatan kemampuan kolaboratif dan tiga kali tes kemampuan kognitif secara berkelanjutan.

Penelitian ini dilakukan di Sekolah Menengah Atas (SMA) Negeri 1 Natar. Penelitian ini dilakukan dengan melaksanakan pembelajaran sebanyak 3 kali pertemuan dengan alokasi waktu 9 jam pelajaran, dimana tiap pembelajaran dialokasikan sebanyak 45 menit.

Populasi dalam penelitian ini adalah seluruh siswa kelas X MIA semester genap Sekolah Menengah Atas (SMA) Negeri 1 Natar tahun pelajaran 2018-2019 yang berjumlah dari 7 kelas yang terdiri dari 252 siswa. Sampel diambil dari populasi dengan teknik cluster random sampling. Sampel yang digunakan dalam penelitian ini adalah kelas X MIA 5 yang terdiri 31 siswa.

Instrumen yang digunakan berupa soal kemampuan kognitif dan rubrik pengamatan kemampuan kolaboratif. Selain itu, digunakan pula instrumen ongoing assesment berupa soal untuk mengetahui hasil keterlaksanaan ongoing assesment pada pembelajaran.

Uji validitas soal tes dikenakan uji pearson. Uji validitas kedua jenis soal tes memperoleh skor correlated item - total correlation > 0,3 sehingga dikatakan valid. Untuk reliabilitas soal tes, digunakan nilai cronbachs alpha., dan diperoleh skor > 0,60 sehingga kedua instrumen tersebut dikatakan reliabel.

Selanjutnya, untuk menjawab tujuan penelitian, uji regresi linier sederhana dilakukan untuk mengetahui pengaruh penerapan ongoing assesment terhadap kemampuan kolaboratif dan kemampuan kognitif siswa, dengan terlebih dahulu menguji normalitas datanya.

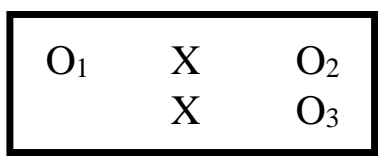

Gambar 1. Desain Penelitian
Keterangan:

$\mathrm{X}=$ Perlakuan penerapan Ongoing Assesment dalam pembelajaran Collaborative Teamwork Learning

$\mathrm{O}_{1}=$ Pretest Hasil Belajar Siswa Kemampuan Kognitif

$\mathrm{O}_{2} \quad$ = Posttest Hasil Belajar Siswa Kemampuan Kognitif

$\mathrm{O}_{3}=$ Hasil Pengamatan Kemampuan Kolaboratif Siswa

(Fraenkel, et al., 2012)

\section{Hasil dan Pembahasan}

\section{Hasil Pengamatan Kemampuan Kolaboratif Siswa}

Penilaian pengamatan akhir kemampuan kolaboratif dan selama penerapan ongoing assesment dilakukan oleh guru saat proses pembelajaran berlangsung. Berdasarkan hasil pengamatan diperoleh rata-rata nilai keterampilan kolaborataif disajikan pada Tabel 1 berikut ini.

Tabel 1. Hasil pengamatan kemampuan kolaboratif siswa

\begin{tabular}{llll}
\hline \multirow{2}{*}{ No } & \multirow{2}{*}{ Parameter } & $\begin{array}{l}\text { Pengamatan } \\
\text { Awal }\end{array}$ & $\begin{array}{l}\text { Pengamatan } \\
\text { Akhir }\end{array}$ \\
\hline 1 & Jumlah siswa & 31 & 31 \\
2 & Nilai terendah & 50 & 69 \\
3 & Nilai tertinggi & 62 & 78 \\
4 & Rata-rata nilai & 58 & 73,45 \\
\hline & Berdasarkan & hasil pengamatan kemampuan
\end{tabular}

kolaboratif siswa pada Tabel 1 , terdapat peningkatan pada pengamatan awal rata-rata nilai pada rentang 50\%-62\% dengan kategori cukup, meningkat pada pengamatan akhir rata-rata nilai pada rentang 69\%$78 \%$ dengan kategori baik.

\section{Hasil Tes Kemampuan Kognitif Siswa}

Tabel 2. Hasil Pretest dan Posttest Kemampuan Kognitif Siswa

\begin{tabular}{llll}
\hline No & Parameter & Pre-test & Post-test \\
\hline 1 & Jumlah siswa & 31 & 31 \\
2 & Nilai terendah & 24 & 57 \\
3 & Nilai tertinggi & 60 & 95 \\
4 & Rata-rata nilai & 43,25 & 76,90 \\
\hline
\end{tabular}

Berdasarkan hasil pretest dan posttest kemampuan kognitif siswa pada Tabel 2, terdapat peningkatan pada hasil pretest dan posttest, diperoleh rata-rata nilai pretest pada rentang $24 \%-60 \%$ dengan kategori buruk-cukup, meningkat pada hasil rata-rata nilai posttest pada rentang 57\%-95\% dengan kategori cukup-baik. 


\section{Hasil Penilaian Ongoing Assesment}

Penilaian ongoing assesment diperoleh dari tiga pertemuan, dimana setiap pertemuan diberlakukan tiga kali penilaian penerapan ongoing assesment. Berdasarkan hasil penilaian diperoleh rata-rata nilai ongoing assesment disajikan pada Tabel 3 berikut ini.

Tabel 3. Hasil penilaian ongoing assesment

\begin{tabular}{lll}
\hline No & Parameter & Ongoing Assesment \\
\hline 1 & Jumlah siswa & 31 \\
2 & Nilai terendah & 68 \\
3 & Nilai tertinggi & 86 \\
4 & Rata-rata nilai & 76,2 \\
\hline
\end{tabular}

Berdasarkan hasil penilaian ongoing assesment pada Tabel 3, diperoleh nilai terendah siswa sebesar 68 dan nilai tertinggi siswa sebesar 86 , sehingga rata-rata nilai ongoing assesment yang diperoleh ialah sebesar 76,2 .

\section{Hasil Uji Normalitas}

Tabel 4. Hasil Uji Normalitas Data dengan Kolmogorov Smirnov

\begin{tabular}{ccc}
\hline \multirow{2}{*}{ No } & \multirow{2}{*}{ Jenis } & Kolmogorov Smirnov \\
& & $\mathrm{Sig}$ \\
\hline 1 & Kemampuan Kolaboratif & 0,92 \\
2 & Kemampuan Kognitif & 0,62 \\
\hline
\end{tabular}

Berdasarkan Tabel 4 diperoleh bahwa nilai signifikansi data kemampuan kolaboratif sebesar 0,92 dan kemampuan kognitif sebesar 0,62, karena Sig. $\geq$ 0,050 maka $\mathrm{H}_{0}$ diterima, artinya sampel berasal dari populasi yang berdistribusi normal sehingga dapat dilakukan uji regresi linier sederhana.

\section{Hasil Uji Regresi Linier}

Tabel 5. Hasil uji t kemampuan kolaboratif dan Kognitif

\begin{tabular}{lll}
\hline Variabel Independen & Variabel Dependen & Sig \\
\hline Ongoing Assesment & Kemampuan Kolaboratif & 0,00 \\
Ongoing Assesment & Kemampuan Kognitif & 0,00 \\
\hline
\end{tabular}

Berdasarkan Tabel 5 diperoleh nilai signifikansi $<0,050$ sehingga $\mathrm{H}_{0}$ ditolak, artinya variabel instrument ongoing assesment dengan model pembelajaran collaborative teamwork learning menggunakan flipchart (x) berpengaruh terhadap kemampuan kolaboratif $\left(\mathrm{Y}_{1}\right)$ dan kemampuan kognitif $\left(\mathrm{Y}_{2}\right)$.

Tabel 6. Hasil uji hipotesis pertama

\begin{tabular}{lcccc}
\hline Model & $r$ & $r^{2}$ & $t_{\text {hit }}$ & $t_{\text {tab }}$ \\
\hline $\begin{array}{l}\text { Ongoing assesment } \\
\text { terhadap Kemampuan } \\
\text { Kolaboratif }\end{array}$ & 0,42 & 0,18 & 2.722 & 1.699 \\
\hline
\end{tabular}

Berdasarkan perhitungan data pada Tabel 6, diperoleh nilai koefisien korelasi $(r)$ sebesar 0,42 , yang artinya hubungan keterlaksanaan ongoing assesment (X) dengan kemampuan kolaboratif (Y) adalah cukup kuat, presentasenya $42 \%$. Jadi, kemampuan kolaboratif siswa dipengaruhi oleh keterlaksanaan ongoing assesment dalam proses pembelajaran yang dikategorikan cukup kuat. Selanjutnya, diperoleh nilai koefisien determinan $\left(r^{2}\right)$ sebesar 0,18 , yang artinya $18 \%$ murni keterlaksanaan ongoing assesment mempengaruhi kemampuan kolaboratif siswa dan $24 \%$ dipengaruhi oleh treatment yang diterapkan.

Berdasarkan perhitungan data pada Tabel 6, diperoleh nilai $t_{\text {hit }}$ dan $t_{\text {tab }}$ untuk menguji hipotesis pertama diperoleh nilai $t_{\text {hit }}=2.722$ dan nilai $t_{t a b}=$ 1.699. Maka, $t_{\text {hit }}>t_{t a b}$, sehingga, dikatakan bahwa ada pengaruh signifikan (nyata) antara keterlaksanaan ongoing assesment terhadap kemampuan kolaboratif siswa dengan taraf signifikan 5\%.

Berdasarkan rumus persamaan regresi linier sederhana diperoleh nilai konstanta $a$ sebesar -2.689 , yang artinya jika keterlaksanaan ongoing assesment bernilai 0 (konstan) maka kemampuan kolaboratif siswa bernilai negatif, yaitu -2.698 . Selanjutnya, nilai koefisien regresi $(b)$ sebesar 2.184, yang artinya setiap kenaikan $1 \%$ keterlaksanaan ongoing assesment pada pembelajaran maka akan mempengaruhi kemampuan kolaboratif siswa sebesar 2,2\%, koefisien bernilai positif artinya terjadi hubungan positif antara penerapan ongoing assesment dengan kemampuan kolaboratif siswa, semakin baik penerapan ongoing assesment pada pembelajaran maka kemampuan kolaboratif siswa akan semakin baik pula.

Alasan pengaruh penerapan ongoing assesment terhadap kemampuan kolaboratif dikategorikan cukup baik adalah karena ketika guru menerapkan sistem penilaian yang berkelanjutan, guru lebih leluasa melakukan convertation, observation, dan survey selama proses pembelajaran, selain itu terdapat inventari rubrik penilaian setiap indikator pencapaian siswa yang dapat mempermudah guru dalam memilah indikator mana yang telah dan yang belum dicapai oleh siswa, lalu diberlakukannya state assesment dan standardized assesment pada pembelajaran, sehingga penilaian dilakukan dari berbagai sudut pandang namun berada dipusat yaitu guru, hal ini sesuai dengan pendapat Conley (2006), bahwa pada skema penjelasan penerapan ongoing assesment, yaitu "different purpose for assesment, different kinds of tests". Penelitian ini mengukur pengaruh hasil belajar yang berbeda jenis yaitu kemampuan kognitif dan kemampuan kolaboratif, maka diberlakukan teknik test dan non-test.

Berdasarkan analisis menggunakan uji regresi linier sederhana diketahui bahwa penerapan instrumen 
ongoing assesment dalam pembelajaran collaborative teamwork learning menggunakan flip chart cukup berpengaruh terhadap kemampuan kolaboratif siswa, penerapan sistem penilaian yang tepat dengan model pembelajaran yang sesuai berpengaruh positif terhadap kemampuan kolaboratif siswa sangat penting dalam menunjang dan memperlancar proses belajar siswa. Seperti yang dikemukakan oleh Haryono (2009) Peningkatan kualitas penilaian guru pada siswa harus melalui meningkatkan keterlibatan siswa, proses dan tindak-lanjut hasil penilaian. Penilaian harus bersifat holistik, artinya mencakup semua aspek dari tujuan pembelajaran, salah satunya aspek sensorik-motorik seperti kemampuan kolaboratif siswa. Berdasarkan penelitian Arias (2018), penilaian berkelanjutan juga sangat cocok digunakan karena penilaian dilakukan secara berlanjut pada saat proses pembelajaran berlangsung, sehingga guru dapat menilai kelemahankelemahan siswa yang masih belum memenuhi indikator kemampuan kolaboratif dengan melakukan feedback dan monitoring.

Tabel 7. Hasil uji hipotesis kedua

\begin{tabular}{lllcc}
\hline Model & $r$ & $r^{2}$ & $t_{\text {hit }}$ & $t_{t a b}$ \\
\hline $\begin{array}{l}\text { Ongoing assesment } \\
\text { terhadap }\end{array}$ & 0,903 & 0,815 & 10.755 & 1.699 \\
Kemampuan Kognitif & & & & \\
\hline
\end{tabular}

Berdasarkan perhitungan data pada Tabel 7 , diperoleh nilai koefisien korelasi $(r)$ sebesar 0,903, yang artinya hubungan keterlaksanaan ongoing assesment (X) dengan kemampuan kognitif (Y) adalah sangat kuat, presentasenya $90 \%$. Jadi, kemampuan kognitif siswa dipengaruhi oleh keterlaksanaan ongoing assesment dalam proses pembelajaran yang dikategorikan sangat kuat. Selanjutnya, diperoleh nilai koefisien determinan $\left(r^{2}\right)$ sebesar 0,815 yang artinya $81 \%$ keterlaksanaan ongoing assesment dapat mempengaruhi kemampuan kognitif siswa dan 9\% dipengaruhi oleh treatment yang diterapkan.

Berdasarkan perhitungan data pada Tabel 7, yang telah dilampirkan pada Lampiran 16 diperoleh nilai $t_{\text {hit }}$ dan $t_{\text {tab }}$ untuk menguji hipotesis pertama diperoleh nilai $t_{\text {hit }}=10.755$ dan nilai $t_{\text {tab }}=1.699$. Maka, $t_{\text {hit }}>t_{t a b}$, sehingga, dikatakan bahwa ada pengaruh signifikan (nyata) antara keterlaksanaan ongoing assesment terhadap kemampuan kognitif siswa dengan taraf signifikan 5\%. Hasil analisis regresi linier sederhana keterlaksanaan ongoing assesment terhadap kemampuan kognitif siswa Sekolah Menengah Atas (SMA).

Berdasarkan rumus persamaan regresi linier sederhana diperoleh nilai konstanta a sebesar -2.342 , yang artinya jika keterlaksanaan ongoing assesment bernilai 0 (konstan) maka kemampuan kognitif siswa bernilai negatif, yaitu -2.342. Selanjutnya, nilai koefisien regresi $(b)$ sebesar 0.002 , yang artinya setiap kenaikan $1 \%$ keterlaksanaan ongoing assesment pada pembelajaran maka akan mempengaruhi kemampuan kognitif siswa sebesar $0,2 \%$, koefisien bernilai positif artinya terjadi hubungan positif antara penerapan ongoing assesment dengan kemampuan kognitif siswa, semakin baik penerapan ongoing assesment pada pembelajaran maka kemampuan kognitif siswa akan semakin baik pula.

Alasan pengaruh penerapan ongoing assesment terhadap kemampuan kognitif dikategorikan sangat baik adalah karena dengan pendapat Isserlis (2005), yaitu dilakukan dalam proses aktivitas belajar secara berkelanjutan dengan mengurangi menulis laporan dan lebih jauh lagi dengan berinteraksi antara guru dan siswa. Selanjutnya hal ini harus dilakukan dengan merespon pertanyaan siswa setiap hari dan memvariasikan berbagai macam pertanyaan yang akan ditanyakan kepada siswa, salah satunya dengan komunikasi secara langsung mengenai jenis kesalahan yang mereka buat dan cara lain dengan memberi perbaikan kesalahan pemahaman mereka secara tanya jawab. Pertanyaan-pertanyaan tersebut diberikan perunit, sehingga siswa lebih memahami pembelajaran secara rinci.

Penerapan ongoing assesment dalam pembelajaran collaborative teamwork learning menggunakan flip chart dapat dijadikan salah satu sistem penilaian dalam pembelajaran yang efektif untuk meningkatkan pembelajaran. Hal ini pula dapat dijadikan salah satu pembelajaran alternatif untuk meningkatkan partisipasi siswa dalam pembelajaran. Karena guru tidak hanya menilai hasil pembelajaran saja, namun menilai proses pembelajaran pula.

Berdasarkan analisis diketahui bahwa penerapan instrumen ongoing assesment dalam pembelajaran collaborative teamwork learning menggunakan flip chart sangat berpengaruh terhadap kemampuan kognitif siswa, penerapan sistem penilaian yang tepat dengan model pembelajaran yang sesuai berpengaruh positif terhadap kemampuan kognitif siswa sangat penting dalam menunjang dan memperlancar proses belajar siswa. Seperti yang dikemukakan oleh Pantiwati (2013), yaitu salah satu prinsip penilaian autentik adalah penilaian berkelanjutan, siswa terus didorong untuk memantau dan mengendalikan studi mereka, hal ini dapat meningkatkan kemampuan kognitif mereka.

Pendapat lain diungkapkan oleh Rustaman (2010), salah satu cara mengumpulkan data pada penilaian portofolio ialah penilaian berkelanjutan, dimana pemberian feedback atau umpan balik sebagai salah satu proses penilaian berkelanjutan yang diprogramkan dengan baik dapat mengembangkan kemampuan siswa untuk mengakses kemampuan kognitif mereka sendiri, dengan demikian mereka dapat memperbaharui pengusaan materi melalui 
feedback atau umpan balik berupa komentar atau catatan peserta didik sebagai masukan untuk bahan perbaikan.

\section{Kesimpulan}

Berdasarkan hasil penelitian yang telah dilakukan, maka dapat disimpulkan penerapan ongoing assesment dalam pembelajaran collaborative teamwork learning menggunakan flip chart memiliki pengaruh yang cukup kuat terhadap kemampuan kolaboratif siswa dan memiliki pengaruh yang sangat kuat terhadap kemampuan kognitif siswa. hal ini dapat dilihat dari nilai koefisien korelasi $(r)$ pada uji regresi linier sederhana bahwa ongoing assesment dalam pembelajaran collaborative teamwork learning menggunakan flip chart dapat mempengaruhi kemampuan kolaboratif dan kemampuan kognitif siswa

\section{Daftar Pustaka}

Arias, R., Marsela, L. (2018). Assesing Speaking Skill through the Implementation of TBLA in Group of Second Grades. Licenciatura en Lenguas Ekstranjeras. 1-22.

Conley, T. 2006. Breaking free from the anxiety trap. Washington D. C: American Psychological Association, pp: 98-105.

Fraenkel, J. R., Wallen, N. E., Hyun, H. H. (2012). How to Design and Evaluate Research in Education. San Fransisco: Mc-Graw Hill Companies.

Haryono, A. (2009). Authentic Assessment dan Pembelajaran Inovatif dalam Pengembangan
Kemampuan Siswa. UM: Jurusan Ekonomi Pembangunan. 2(1): 11.

Isserlis, J. (2005). What You See: Ongoing Assesment in the ESL/Literaly Classroom.

Pantiwati, Yuni. (2013). Authentic Assesment for Improving Cognitiv Skills, Critical-Creatif Thingking and Metacognitiv Awareness. Universitas Muhammadiyah Malang: Jurnal Ilmu Pendidikan. (4): 6.

Permendikbud. (2013). Permendiknas No. 65 Tahun 2013 tentang Standar Proses. Bandung.

Rahmawati, I., Abdurahman, Suyatna, I. (2015). Penerapan Ongoing Assesment Menggunakan Flash Card terhadap Hasil Belajar Siswa SMA. Jurnal Pembelajaran Fisika. Vol 3 (4): 30-31.

Rustaman, NY. (2010). Pendidikan dan Penelitian Sains dalam Mengembangkan Keterampilan Berpikir Tingkat Tinggi untuk Pembangunan Karakter. Seminar Nasional VIII Pendidikan Biologi. 2:16-32.

Sari, I. S., Nyeneng, I. D. P., Rosidin, U. (2014). Penerapan Ongoing Assesment untuk Meningkatkan Metakognisi dan Hasil Belajar Fisika Siswa. Jurnal Pembelajaran Fisika. Vol 2 (6): 16.

Surahman, A. (2013). Pengaruh Ongoing Assessment Teknik If-At (Immediate Feedback Assessment Technique) Terhadap Hasil Belajar Siswa Melalui Model Team Based Learning Pada Materi Pokok Gerak Melingkar. Skripsi. Fakultas KIP, Universitas Lampung. 